\title{
The Relationship between Writing Dispositions and Intelligence Domains of Gifted Students
}

\author{
Murat Sengul ${ }^{1}$ \\ ${ }^{1}$ Nevsehir Haci Bektas Veli University, Department of Turkish Language Education, 50300 Nevsehir / Turkey \\ Correspondence: Murat Sengul, Nevsehir Haci Bektas Veli University, Department of Turkish Language Education, \\ 50300 Nevsehir / Turkey E-Mail: muratsengul@ nevsehir.edu.tr
}

Received: September 16, 2015

Accepted: October 9, 2015

Online Published: October 12, 2015

doi:10.5430/ijhe.v4n4p207

URL: http://dx.doi.org/10.5430/ijhe.v4n4p207

\begin{abstract}
This study investigated the relationship between intelligence profiles of gifted secondary school students and their writing dispositions. The study group comprised of 61 secondary school students in Erzurum Cevat Dursunoglu and Elazig Science and Art Center in Turkey. Data collection tools were Multiple Intelligence Inventory, Writing Disposition Scale and Personal Information Form. The results revealed that logical-mathematical, naturalist, bodily-kinesthetic and visual-spatial intelligences of gifted students were stronger than others; they had "partially negative/positive" attitudes in terms of writing tendencies; and there was a moderately positive and significant relationship between their verbal-linguistic, social, intrapersonal and naturalist intelligences and their writing tendencies.
\end{abstract}

Keywords: Gifted students, Intelligence domains, Writing disposition

\section{Introduction}

Writing, an expressive skill, is one of the most important communication styles used by humans for thousands of years. The invention of writing offered humanity a new communication channel besides speaking, facilitating information and culture transfer and contributing significantly to civilization (Coskun, 2007). Therefore, the disposition towards written communication is considered to be one of the most important indicators of development.

Writing is a skill that contains the processes of expressing information obtained in different ways through written communication channels (Carter, Bishop, \& Kravits, 2002) and is an the effort of the act of expressing thoughts, wishes and events by using certain symbols (Ozbay, 2006). Turning this skill into a pleasurable habit depends on offering training in writing skills in primary schools (Gocer, 2010).

The instructional process of writing includes achieving a high level aim which is to enable students to express their emotions, thoughts and impressions for a certain purpose. With this in mind, it is aimed to develop writing skills of the students and expected to see behaviors from students showing that they reach the pre-determined aims (Gocer, 2010).Individuals are born with a genetic cognitive and affective competences with certain inherited characteristics and their creative intelligence and creativity competences come from inheritance. "Each individual needs to be given the opportunity to fully actualize their inherited characteristics and reveal their potential" (San, 2011: 11).

The educational processes that promote research, free and critical thinking, experimentation and language use instead of memorization contribute to raising individuals that are creative in science, technology and arts (San, 2011). The instructional process of writing needs to be considered in two different stages: 1- The stage of acquisition, 2- The stage of development. The stage of acquisition refers to learning basic writing knowledge and acquiring skills at a reasonable level. It is during this stage that letters, syllables, words and sentences are learned. On the other hand, it is during the stage of development that students learn how to use the skills that they have acquired in effective written communication (Akyol, 2008).

Written texts reveal the most concrete form of people's linguistic capabilities. It is during primary and secondary school years that the most basic steps towards good written communication are made and peoples' writing tendencies become clearer. Training given in primary and secondary schools years may help individuals express themselves better in writing make them better writers in the future.

Sperling (1996) views writing as shared social and cultural meaning-making efforts based on personal and social goals. Hayes (1996) emphasizes that writing is a work of art created by people within the cycle of social interaction 
(Sperling, 1996; Hayes, 1996 as cited in Weigle, 2007). This shows that the environment, learning experiences and the social context have a significant role in shaping students' writing tendencies and achievement.

Considering the social context, science and art centers are important places where multiple intelligence based curricula are practiced and gifted individuals who will be the possible leaders of the country are educated. These centers are places where gifted children are grouped according to their characteristics and levels, and special curricula are developed and implemented based on these characteristics and levels (Ataman, 1998).

Many definitions of gifted children can be found in the literature. The most widely accepted definition is as follows: "Children who outperform their peers in one or more mental capabilities or intelligences and have strong creativity skills and a high sense of duty regarding completing tasks." These children outperform $98 \%$ of a randomly made cluster of their peers (Ataman, 1998).

Gardner (1993) stresses that not every characteristic displayed by people can be considered as an intelligence domain. In order to be considered intelligence, a skill needs to (1) have a number of symbols, (2) be valued in that culture, (3) produce products or services, and (4) solve problems.

The theory of multiple intelligences was first presented by Howard Gardner in 1983 in his book "Frames of Mind: The Theory of Multiple Intelligences". The theory was put forward as a result of a study conducted in Boston University Medical School and Boston Retirement Medical Center, which examined the development of cognitive potentials of normal and gifted children as well as intellectual disabilities caused by brain damage. According to Gardner, people who have lost their musical ability can still talk and those who have lost their linguistic ability can still sing. While an ability is lost, another can be maintained. Then, it is not possible that humans own one single type of intelligence. This belief not only introduced Gardner to the world of brain research but also helped him develop his "Theory of Multiple Intelligences" (Gardner, 1983). This theory substantially weakens the effect of traditional intelligence tests which mainly based on linguistic and mathematical intelligences (Demirel, 2000). Stating that intelligence has a very narrow definition, Gardner mentioned the presence of at least seven basic intelligences in his 1983 book, and later added the naturalist intelligence and argued that the 9th one may be existentialist intelligence. The theory states that there are eight different types of intelligences in humans: verbal-linguistic, logical-mathematical, visual-spatial, musical-rhythmic, bodily-kinesthetic, interpersonal, intrapersonal, and naturalist. When writing, students mostly use verbal-linguistic intelligence because they mostly think in words and express their thoughts with them. They also use logical-mathematical intelligence when they make connections between information; visual-spatial intelligence when they make judgments by using pictures and perceptions; interpersonal intelligence when they communicate in writing and when they understand or interpret others' feelings, thoughts and behaviors; musical-rhythmic intelligence when they think in sounds, notes and rhythms and when they listen to music as they write; intrapersonal intelligence as they reflect their own feelings in their written texts; and naturalist intelligence when they write a text about what can be done to raise people's awareness of the environment. Therefore, as Armstrong (1994) also states, different intelligences interplay with each other in a complex process.

Educating gifted individuals that comprise approximately $2 \%$ of societies, making them productive and enabling them to use their potential for social advancement is important for the well-being of the societies in the future. Gifted individuals lead their societies and accelerate development and change with their leadership qualities, motivations, decisiveness, quick thinking and creative problem-solving abilities (MEB, 2013). Identifying the primary intelligence domains of these individuals, the extent of their positive writing tendencies and the problems in their writing training is important to maximize opportunities, develop their interest areas, abilities and creativity, and make them more useful to their society.

This study was conducted to reveal the results of a set of implementations regarding the identification of gifted secondary school students' intelligence domains and writing tendencies at science and art centers where these students are educated in Turkey.

The study examined the relationship between the Multiple Intelligences Inventory scores and writing dispositions of gifted secondary school students attending science and art centers. Following research questions guided the study:

1- Do students' Multiple Intelligences Inventory scores vary by type of intelligence?

2- How are students' writing dispositions?

3- Is there a significant relationship between students' intelligence domains and their writing dispositions? 


\section{Method}

\subsection{Research Model}

This quantitative study used surveys to collect data including Multiple Intelligence Inventory and Writing Disposition Scale. Karasar (2002) defines survey as a screening conducted on large population or a group or sample of it in order to reach conclusions about that population.

\subsection{Study Group}

The participants of the study included 70 secondary school students attending the Erzurum Cevat Dursunoglu and Elazig Art and Science Centers in Turkey. Data from nine individuals were excluded from the analysis due to missing or inconsistent answers in the initial evaluation and the final study group comprised of 61 students.

The demographics of the participating students are shown in Table 1.

Table 1. The demographics of participants

\begin{tabular}{llcc}
\hline & & $f$ & $\%$ \\
\hline \multirow{2}{*}{ Gender } & Female & 21 & 34.4 \\
& Male & 40 & 65.6 \\
& Grade 5 & 22 & 36.1 \\
Grade Level & Grade 6 & 17 & 27.9 \\
& Grade 7 & 12 & 19.6 \\
Science and Art Center & Grade 8 & 10 & 16.4 \\
Attended & Erzurum Cevat Dursunoglu Science and Art Center & 29 & 47.5 \\
\hline Total & Elazig Science and Art Center & 32 & 52.5 \\
\hline
\end{tabular}

\subsection{Data Collection Tools}

Multiple Intelligence Inventory (MII): The inventory was developed by Ozden (2003). It is a Likert type scale (1= Not true for me; $2=$ Somewhat true for me; $3=$ Partially true for me; $4=$ Rather true for me; $5=$ Completely true for me) consisting of 10 sections with 8 items each, thereby making a total of 80 items.

Writing Disposition Scale (WDS): This scale was developed by Piazza and Siebert (2008) and adapted to Turkish and tested for reliability and validity by Iseri and Unal (2010). It is a Likert type scale (5=Completely agree; $4=$ Agree; $3=$ Undecided; $2=$ Disagree; $1=$ Completely disagree) in 3 dimensions (Confidence, Continuity, Passion) with 21 items. Iseri and Unal (2010) calculated the Cronbach Alpha Coefficient for reliability and found it to be .874 for the entire scale, .734 in the confidence dimension; .639 in the continuity dimension and .882 in the passion dimension.

Personal Information Form: This form included questions aiming to obtain information about students' gender, grade level and the science and art center they were attending.

\subsection{Data Analysis}

The scores from the Multiple Intelligence Inventory were evaluated according to the scoring criteria given by Ozden (2003). The scores that each student gathered from the 10 different parts of the inventory were added and their total scores in different intelligence domains were identified. Those domains with a score between 41-50 were considered highly developed, between 31-40 developed, between 21-30 moderately developed, between 11-20 somewhat developed, and between 0-10 not developed.

The data from the Writing Disposition Scale were analyzed as follows: The 0.80 intervals obtained by dividing the value difference of the Likert type scale $(5-1=4)$ by the value judgment $(5)$ showed the limits of students' views on the items of the scale and thus their writing tendencies. Accordingly, views that corresponded to the arithmetic mean in the interval 1.00-1.80 showed "very negative tendencies" towards writing; between 1.81-2.60 "negative tendencies"; between 2.61-3.40 "partially negative/positive tendencies", between 3.41-4.20 "positive tendencies", and between 4.21-5.00 "very positive tendencies" by students. Data from the personal information forms, the Multiple Intelligence Inventory and the Writing Disposition Scale were digitized, computed and analyzed on "SPSS Statistics 17.0 for Windows". Frequencies, percentages, arithmetic means and the Pearson Moments Multiplication Correlation technique for paired correlations between variables were used to analyze the data. 


\section{Results}

This section offers an analysis of the distribution of students' multiple intelligence profiles according to the Multiple Intelligence Inventory, the development level of students in each domain, their writing dispositions, and the relationship between these dispositions and intelligence domains. The results are presented in tables.

Table 2 shows total scores, arithmetic means and the standard deviation of the distribution of student scores on each section of the Multiple Intelligence Inventory.

Table 2. Total scores, means and standard deviation of student scores on the different parts of the Multiple Intelligence Inventory

\begin{tabular}{|c|c|c|c|c|c|c|c|c|c|c|c|c|c|}
\hline \multirow{2}{*}{ Intelligence Domains } & \multicolumn{10}{|c|}{ Mean Score for Each Part on the Inventory } & \multirow{2}{*}{$\begin{array}{l}\text { Total } \\
\text { Score }\end{array}$} & \multirow{2}{*}{ Mean } & \multirow{2}{*}{$S D$} \\
\hline & 1 & 2 & 3 & 4 & 5 & 6 & 7 & 8 & 9 & 10 & & & \\
\hline $\begin{array}{l}\text { Verbal-Linguistic } \\
\text { Intelligence }\end{array}$ & 4.43 & 3.93 & 2.51 & 4.44 & 3.51 & 2.69 & 3.48 & 4.18 & 4.10 & 4.02 & 37.22 & 3.72 & 0.69 \\
\hline $\begin{array}{l}\text { Logical-Mathematical } \\
\text { Intelligence }\end{array}$ & 4.72 & 4.25 & 4.63 & 4.52 & 4.38 & 4.22 & 4.52 & 4.38 & 4.47 & 4.48 & 44.57 & 4.46 & 0.70 \\
\hline $\begin{array}{l}\text { Visual-Spatial } \\
\text { Intelligence }\end{array}$ & 4.37 & 4.30 & 4.35 & 3.92 & 3.73 & 3.23 & 3.82 & 4.45 & 4.10 & 4.17 & 40.43 & 4.04 & 0.80 \\
\hline $\begin{array}{l}\text { Musical-Rhythmic } \\
\text { Intelligence }\end{array}$ & 2.97 & 3.80 & 4.30 & 3.27 & 4.25 & 3.62 & 3.62 & 3.90 & 3.95 & 4.10 & 37.77 & 3.78 & 0.77 \\
\hline $\begin{array}{l}\text { Bodily-Kinesthetic } \\
\text { Intelligence }\end{array}$ & 4.02 & 3.97 & 4.37 & 4.28 & 4.58 & 3.35 & 4.17 & 4.43 & 3.53 & 4.03 & 40.74 & 4.07 & 0.79 \\
\hline $\begin{array}{l}\text { Interpersonal } \\
\text { Intelligence }\end{array}$ & 3.98 & 3.20 & 4.15 & 4.20 & 3.67 & 3.93 & 4.10 & 3.87 & 4.10 & 4.45 & 39.65 & 3.97 & 0.76 \\
\hline $\begin{array}{l}\text { Intrapersonal } \\
\text { Intelligence }\end{array}$ & 4.05 & 2.92 & 4.37 & 2.75 & 4.27 & 2.45 & 3.75 & 3.62 & 4.43 & 4.28 & 36.88 & 3.69 & 0.74 \\
\hline Naturalist Intelligence & 4.17 & 4.32 & 4.02 & 3.90 & 3.93 & 3.73 & 4.38 & 4.38 & 4.35 & 4.27 & 41.45 & 4.15 & 0.78 \\
\hline
\end{tabular}

The total and mean scores in Table 2 revealed that the primary intelligence domains of gifted students are as follows respectively: Logical-mathematical intelligence, naturalistic intelligence, bodily-kinesthetic intelligence, visual-spatial intelligence, intrapersonal intelligence, musical-rhythmic intelligence, verbal-linguistic intelligence, and intrapersonal intelligence. It can be seen that the logical-mathematical, visual-spatial, bodily-kinesthetic and naturalistic intelligences of the students were highly developed, while their verbal-linguistic, musical-rhythmic, interpersonal and intrapersonal intelligences were developed.

The development level of students in each intelligence domain was as follows (Table 3):

Table 3. Students' development levels in each intelligence domains

\begin{tabular}{lcccccccccc}
\hline & \multicolumn{8}{c}{ Development Levels of Intelligence Domains } \\
\cline { 2 - 12 } Intelligence Domains & $\begin{array}{c}\text { Not } \\
\text { developed }\end{array}$ & $\begin{array}{c}\text { Somewhat } \\
\text { developed }\end{array}$ & Moderate & Developed & $\begin{array}{c}\text { Highly } \\
\text { developed }\end{array}$ \\
\cline { 2 - 18 } & $f$ & $\%$ & $f$ & $\%$ & $f$ & $\%$ & $f$ & $\%$ & $f$ & $\%$ \\
\hline Verbal-Linguistic Intelligence & - & - & 2 & 3.3 & 6 & 9.7 & 32 & 52.4 & 21 & 34.3 \\
Logical-Mathematical Intelligence & - & - & 2 & 3.2 & - & - & 8 & 13 & 51 & 83.7 \\
Visual-Spatial Intelligence & - & - & 3 & 4.8 & 3 & 4.8 & 16 & 26.1 & 39 & 64 \\
Musical-Rhythmic Intelligence & - & - & 2 & 3.2 & 7 & 11.3 & 29 & 47.6 & 23 & 37.6 \\
Bodily-Kinesthetic Intelligence & - & - & 2 & 3.2 & 3 & 4.8 & 18 & 29.3 & 38 & 62.3 \\
Interpersonal Intelligence & 1 & 1.6 & - & - & 5 & 8 & 21 & 34.3 & 34 & 55.7 \\
Intrapersonal Intelligence & - & - & 3 & 4.8 & 5 & 8.1 & 34 & 55.9 & 19 & 31.1 \\
Naturalist Intelligence & - & - & 1 & 1.6 & 5 & 8.1 & 15 & 24.5 & 40 & 65.6 \\
\hline
\end{tabular}

Table 3 shows that students' development levels in different domains were clustered in "highly developed" and "developed". However, there is a considerable number of students with "moderate" development levels too.

Logical-mathematical intelligence had the greatest number and ratio of students in the "highly developed" level $(\mathrm{f}=51 ; 83.7 \%)$. This was followed by naturalistic intelligence $(\mathrm{f}=40 ; 65.6 \%)$, Visual-spatial intelligence $(\mathrm{f}=39 ; 64 \%)$, Bodily-kinesthetic intelligence ( $\mathrm{f}=38 ; 62.3 \%$ ), Interpersonal intelligence ( $\mathrm{f}=34 ; 55.7 \%)$, Musical-rhythmic intelligent $(\mathrm{f}=23 ; 37.6 \%)$, Verbal-linguistic intelligence $(\mathrm{f}=21 ; 34.3 \%)$ and Intrapersonal intelligence $(\mathrm{f}=19 ; 31.1 \%)$, respectively. 
Data from the Writing Disposition Scale implemented on gifted students were as follows (Table 4):

Table 4. Mean scores and standard deviation values of the Writing Disposition Scale

\begin{tabular}{lcc}
\hline Dimensions of the scale & Mean & SD \\
\hline Confidence & 4.07 & 0.80 \\
Continuity & 2.90 & 0.96 \\
Passion & 2.99 & 1.03 \\
\hline Overall & 3.32 & 0.68 \\
\hline
\end{tabular}

Student scores on the "Writing Disposition Scale" showed that the mean score of the items in the "Confidence" dimension was 4.07. This mean score reveals that the students "Agreed" that they had the following items and skills: "Writing good texts", "Having the skills to write good texts", "Easily reaching challenging writing goals", "Being successful on every writing task asked by the teacher", "Being among the top students regarding written work" and "Always taking high grades in writing". Based on these findings, it may be argued that the students had a "positive" attitude regarding confidence in writing.

Table 4 shows that the mean score of student answers to the items in the "Continuity" dimension of the scale was 2.90. This means that students were undecided in the following items and skills: "Frequently asking for extra time to revise a text", "Spending time on fixing the problems in writing", "Generally spending too much time on writing" and "Allowing ample time to produce a good piece of writing". These findings imply that students had a partially positive/negative attitude in the Continuity dimension.

According to Table 4, the mean score of student answers to the items in the Passion dimension was 2.99. This finding shows that the students were also undecided in the following items and skills: "Liking writing", "Writing being the favorite activity at school", "Writing making students feel good", "Writing at every opportunity", "Seeing writing as fun", "Writing in spare times", "Valuing writing", "Devoting self to writing", "Looking forward to writing class", "Seeing writing as a satisfactory action" and "Wanting to do more writing at school". These findings mean that students had a partially negative/positive attitude regarding passion in writing.

The overall mean score in Table 4 shows that the students were at the level "undecided" and had partially negative/positive writing tendencies.

Table 5. Descriptive data on students' writing dispositions

\begin{tabular}{|c|c|c|c|c|c|c|c|c|c|c|}
\hline \multirow{3}{*}{ Dimensions of the Scale } & \multicolumn{10}{|c|}{ Students' Writing Dispositions } \\
\hline & \multicolumn{2}{|c|}{$\begin{array}{c}\text { Very } \\
\text { negative }\end{array}$} & \multicolumn{2}{|c|}{ Negative } & \multicolumn{2}{|c|}{$\begin{array}{c}\text { Partially } \\
\text { negative/positive }\end{array}$} & \multicolumn{2}{|c|}{ Positive } & \multicolumn{2}{|c|}{$\begin{array}{c}\text { Very } \\
\text { positive }\end{array}$} \\
\hline & $f$ & $\%$ & $f$ & $\%$ & $f$ & $\%$ & $f$ & $\%$ & $f$ & $\%$ \\
\hline Conf & 0 & 0 & 3 & 4,8 & 9 & 14.8 & 19 & 31.2 & 30 & 49.2 \\
\hline Conti & 10 & 16.4 & 15 & 24.5 & 17 & 27.8 & 11 & 18.1 & 8 & 13.1 \\
\hline Passion & 8 & 13.1 & 13 & 21.2 & 18 & 29.4 & 15 & 24.6 & 7 & 11.4 \\
\hline
\end{tabular}

The mean scores of the answers to the items in the "Confidence" dimension of the scale showed that the majority of gifted students $(80.4 \%)$ responded "Agree" and "Completely agree", and have positive ( $\mathrm{f}=19 ; 31.2 \%)$ and very positive ( $\mathrm{f}=30 ; 49.2 \%)$ attitudes.

On the other hand, most answers in the "Continuity" and "Passion" dimensions were "Undecided", "Disagree" and "Agree", thus showing partially negative / positive, negative and positive attitudes.

The presence of a significant relationship between students' intelligence domains and writing disposition was examined by using the Pearson Moments Correlation technique (Table 6). 
Table 6. Descriptive data about the relationship between students' intelligence domains and writing dispositions

\begin{tabular}{lcccc}
\hline \multirow{2}{*}{ Intelligence Domains } & Relationship & \multicolumn{3}{c}{ Dimensions of the Writing Disposition Scale } \\
\cline { 2 - 5 } and Significance & Confidence & Continuity & Passion \\
\hline \multirow{2}{*}{ Verbal-Linguistic Intelligence } & $\mathrm{r}$ & $.351^{* *}$ & -.120 & $.304^{*}$ \\
& $\mathrm{p}$ & .006 & .355 & .017 \\
Logical-Mathematical Intelligence & $\mathrm{r}$ & .235 & -.074 & .058 \\
& $\mathrm{p}$ & .068 & .573 & .657 \\
Visual-Spatial Intelligence & $\mathrm{r}$ & $.369^{* *}$ & -.081 & .148 \\
& $\mathrm{p}$ & .003 & .535 & .254 \\
Musical-Rhythmic Intelligence & $\mathrm{r}$ & .118 & -.029 & .053 \\
& $\mathrm{p}$ & .364 & .826 & .686 \\
Bodily-Kinesthetic Intelligence & $\mathrm{r}$ & .247 & .003 & .047 \\
& $\mathrm{p}$ & .055 & .984 & .718 \\
Interpersonal Intelligence & $\mathrm{r}$ & $.320^{*}$ & -.119 & .126 \\
& $\mathrm{p}$ & .012 & .363 & .334 \\
Intrapersonal Intelligence & $\mathrm{r}$ & $.317^{*}$ & -.198 & $.346^{* *}$ \\
\multirow{2}{*}{ Naturalist Intelligence } & $\mathrm{p}$ & .013 & .126 & .006 \\
& $\mathrm{r}$ & $.322^{*}$ & -.024 & .229 \\
$* * \mathrm{p}<0.01 ; * \mathrm{p}<0.05$ & $\mathrm{p}$ & .012 & .856 & .076 \\
\hline
\end{tabular}

There is a moderate, positive and significant relationship between the verbal-linguistic intelligence of gifted students and the scores they obtained on the "Confidence" dimension of the scale $(\mathrm{r}=.351 ; \mathrm{p}<.01)$. It can be said that as students' verbal-linguistic intelligence develops, so does their self-confidence in writing. There was a moderate, positive and significant relationship between the students' visual-spatial intelligence and the scores they obtained from the "Confidence" dimension of the scale too $(\mathrm{r}=.369 ; \mathrm{p}<.01)$. This shows that as students' visual-spatial intelligence develops, so does their self-confidence in writing. A similar relationship was also found between students intrapersonal intelligence and their passion for writing $(r=.346 ; p<.01)$. This suggests that high intrapersonal intelligence may encourage passion for writing.

A low, positive and significant relationship was found between the scores in the "Confidence" dimension and the interpersonal, intrapersonal and naturalistic intelligence sections of the Multiple Intelligences Inventory, and the scores in the "Passion" dimension and the "Verbal-Linguistic Intelligence" section of the Inventory. It was concluded that students' interpersonal, intrapersonal and naturalistic intelligences had a positive effect on their self-confidence in writing, while their verbal-linguistic intelligence had a positive effect on their passion for writing.

No relationship was found between students' scores from the "Continuity" dimension and the scores they obtained from the items in each intelligence domain of the Inventory. This finding is important because it shows that gifted student experiences no timing problems when they write.

\section{Discussion and Conclusion}

This study was based on the belief that "Similar to all other linguistic skills, the development of writing skill also rest on the identification of individuals' interests in and tendencies towards writing", and it focused on the relationship between the intelligence domains of students who receives education at science and art centers and who may be accepted as community engineers of the future and their writing dispositions. The results showed that considering the scores of gifted students for each intelligence domain, their primary intelligences were as follows: Logical-mathematical intelligence, naturalistic intelligence, bodily-kinesthetic intelligence, visual-spatial intelligence, interpersonal intelligence, musical-rhythmic intelligence, verbal-linguistic intelligence and intrapersonal intelligence, respectively. Students' logical-mathematical, visual-spatial, bodily-kinesthetic and naturalistic intelligences were "highly developed", while their verbal-linguistic, musical-rhythmic, interpersonal and intrapersonal intelligences were "developed". Writing dispositions are basically more related to verbal-linguistic intelligence than other domains. It is thus worth noting that students' verbal-linguistic intelligence levels were at the "developed" level rather than "highly developed".

In a study by Akar (2006), students' primary intelligences were verbal-linguistic, interpersonal, logical-mathematical, visual, intrapersonal, musical, bodily and naturalistic, respectively. Erman (2003) studied the intelligence types of fourth grade students and found that their interpersonal intelligence was highest, followed by logical-mathematical intelligence, visual intelligence and intrapersonal intelligence, respectively (as cited in Ozturkmen, 2006). Our 
findings were not similar to the findings of these two studies.

The scores obtained from the "Writing Disposition Scale" showed that students have "positive" attitudes regarding confidence, and "partially positive/negative" attitudes regarding continuity and passion. The overall mean score also revealed "partially negative/positive" regarding writing disposition.

In a study conducted on 387 primary students for determining their writing dispositions, Bas and Sahin (2013) found that students' perceptions of $\mathrm{M}=3.13$ were in the confidence sub dimension, $\mathrm{M}=2.82$ in the continuity sub dimension, and $\mathrm{M}=2.82$ in the passion sub dimension, showing that primary school students had a "low" writing disposition on average. The findings of the current study showed that "a lack of will to write" (Sahin, 2013) and "the failure of teachers in making students like writing" (Ozbay, 2000; Temizkan, 2003; Coskun, 2006; Arıc1 and Ungan, 2008; Iseri, 2010) are also true for gifted students and there is a need to include activities to improve gifted students' writing dispositions.

The study found a moderate, positive and significant relationship between gifted students' verbal-linguistic, intrapersonal, interpersonal and naturalistic intelligences and their writing dispositions. Therefore, it may be argued that developing students' verbal-linguistic, interpersonal, interpersonal and naturalistic intelligences contributes to the development of their writing skills.

In a study titled as "A Comparative Study on the Multiple Intelligences of 3rd, 4th and 5th Graders and Their Academic Achievement", Konur (2010) concluded that as students' Turkish achievement scores increased, so did their verbal-linguistic, interpersonal, logical-mathematical and naturalistic intelligences. Tufekcioglu (2010) studied a total of 120 primary school students and found a positive but weak relationship between the participants' confidence, continuity and passion scores and their composition achievement scores. Bas and Sahin (2012) studied 474 primary school students and found significant and positive relationships between students reading attitudes, writing dispositions and Turkish academic achievement. In the light of the pre-mentioned studies, it can be concluded that writing achievement basically leads to academic achievement, which is a finding in line with that of the current study.

\section{Recommendations}

The theory of multiple intelligences is considered to be an important theory which may help to change the traditional monotonous instructional methods with innovative and effective ways. . It is a method that positively affects students' intellectual development, and the curricula developed by taking into account the theory may be effectively used to improve student potential and maximize individual success as well as the overall success of education. The curricula into which multiple intelligence theory is incorporated may also break monotonous structure of the lessons and enable activities that addresses each intelligence type.

Multiple Intelligence theory asserts that intelligence is not unidimensional; on the contrary; it asserts that each individual possesses different intelligences at different degrees; all intelligences are unique and special resources for self-actualization; and there is need for an educational approach that considers individual differences among people. Therefore, Turkish teachers of gifted students should first identify primary intelligence domains of students, decide on the strategies/methods/techniques that best improve students' writing dispositions based on their intelligences, use these more often in their courses, and offer constructive feedback to students regarding their products. This may enable gifted students, whose learning styles, interests, abilities and tendencies are different, to realize not what they can already do with their writing skills but how much more they are capable of doing. Such an awareness raising may help gifted students see writing as a creative activity, and turning them into skillful writers.

\section{References}

Akar, K. (2006). Ilkogretim 6., 7., 8. sinif ogrencilerinin coklu zekâ kuramina gore sahip olduklari zeka alanlari ve akademik basarilarinin karsilastirilmasi. [Comparing the academic achievements and the intelligence domains of the 6th, 7th and 8th grade students have at the primary school according to the multiple intelligence theory]. (Unpublished master's thesis), Bursa: Uludag University Institute of Health Sciences.

Akyol, H. (2008). Yeni programa uygun Turkce ogretim yontemleri. [Turkish teaching methods of appropriate to the new program]. Ankara: Kok Yayincilik.

Arici, A.F. \& Ungan, S. (2008). İlkogretim ikinci kademe ogrencilerinin yazili anlatim calismalarinin bazi yonlerden degerlendirilmesi. [An evaluation of secondary school students' writing mistakes with respect to some points]. Dumlupinar Universitesi Sosyal Bilimler Dergisi, (20), 315-327.

Armstrong, T. (1994). Multiple intelligences in the classroom. Alexandria-Virginia: ASCD. 
Ataman, A. (1998). Ustun zekalilar ve ustun yetenekliler. [Gifted and talented students]. In S. Eripek (Ed.), Ozel Egitim. [Special education]. (pp. 171-194), Eskisehir: Anadolu University Open Education Faculty Publications.

Ayaydin, A. (2009). Egitimde coklu zekâ yansimalari ve gorsel sanatlar. [In education reflections of multiple intelligences and visual arts]. Dicle Universitesi Ziya Gökalp Egitim Fakultesi Dergisi, (13), 52-62.

Bas, G., \& Sahin, C. (2012). İlkogretim 6. 7. ve 8. sinif ogrencilerinin okuma tutumlari ve yazma egilimleri ile Turkce dersindeki akademik basarilari arasindaki iliski. [Correlation amongst reading attitudes, writing dispositions and academic success of elementary 6th, 7th and 8th grade students in Turkish course]. Turkish Studies -International Periodical for the Languages, Literature and History of Turkish or Turkic-, 7(3), 555-572.

Bas, G. \& Sahin, C. (2013). İlkogretim ogrencilerinin yazma egilimlerinin farkli degiskenler acisindan incelenmesi. [Investigating writing dispositions of elementary school students from different variables]. Sakarya University Journal of Education, 3(1), 32-42.

Buyukozturk, S. (2006). Sosyal bilimler icin veri analizi el kitabi. [Manual data analysis for social sciences]. Ankara: Pegem A Yayincilik.

Carter, C., Bishop, J., \& Kravits, S.L. (2002). Key to effective learning. New Jersey: Printice Hall.

Coskun, E. (2007). Yazma becerisi. [Writing skills]. In A. Kirkkilic and H. Akyol (Ed.), Illkogretimde Turkce ogretimi. [Turkish language teaching in primary education]. (pp. 49-91), Ankara: Pegem A Yayincilik.

Coskun, İ. (2006). Ilkogretim 5. sinif ogrencilerinin kompozisyon yazma becerileri uzerine bir arastirma. [A research on writing skills of 5th grade pupils in elementary schools]. (Unpublished master's thesis), Istanbul: Marmara University Institute of Educational Sciences.

Demirel, O. (2000). Planlamadan uygulamaya ogretme sanati. [The art of teaching from planning to implementation]. Ankara: Pagem A Yayincilik.

Gardner, H. (1983). Frames of mind: The theory of multiple intelligences. New York: Basic Books.

Gardner, H. (1993). Multiple intelligences: The theory in practice. New York: A Division of Harper Collins Publishers.

Gocer, A. (2010). Turkce ogretiminde yazma egitimi. [Writing education in Turkish teaching]. Uluslararasi Sosyal Arastirmalar Dergisi, 3(12), 178-195.

Incirci-Ocalan, A. (2007). Yabanci dil ogretmenlerinin coklu zeka duzeyleri ile kullandiklari yabanci dil ogretim yontemlerinin iliskisi. [The relationship between the foreign language teachers' multiple intelligence levels and foreign language teaching methods they use]. (Unpublished master's thesis), Istanbul: Yeditepe University Institute of Social Sciences.

Karasar, N. (2002). Bilimsel arastirma yontemi. [Scientific research method]. Ankara: Nobel Yayin Dagitim.

Konur, M. (2010). Illkogretim 3, 4 ve 5. sinif ogrencilerinin coklu zeka kuramina gore sahip olduklari zeka alanlari ve akademik basarinin karsilastirilmasi. [Comparision of the field of intelligence and academic success of third,forth and fifth grade primary students according to multiple intelligence theory]. (Unpublished master's thesis), Istanbul: Yeditepe University Institute of Social Sciences.

MEB (2013). Ustun yetenekli bireyler strateji ve uygulama plani 2013-2017. [Gifted individuals strategy and implementation plan 2013-2017]. Ankara: Millî Egitim Bakanligi Ozel Egitim ve Rehberlik Hizmetleri Genel Mudurlugu Yayinlari.

Ozbay, M. (2000). Illkogretim okulu ogrencilerinin yazili anlatim becerileri: Alan arastirmasi. [Writing skills of primary school students: Field research]. Ankara: Bizim Buro Basimevi.

Ozbay, M. (2006). Turkce ozel ogretim yontemleri II. [Turkish special teaching methods II]. Ankara: Oncu Kitap ve Yayincilik.

Ozturkmen, B. (2006). Ortaogretim ogrencilerinin coklu zeka kuramina gore zeka alanlariyla ogrenme stratejileri arasindaki iliskinin incelenmesi (Gaziantep ornegi). [The relationship between learning strategies and the highschool student's intelligence catagory according to multiple intelligence theory (Gaziantep sample)]. (Unpublished master's thesis), Gaziantep: Gaziantep University Institute of Social Sciences. 
San, İ. (2011). Yaraticilikta temel kavramlar. [The basic concepts of creativity]. In A. Ozturk (Ed.), Okuloncesinde yaraticilik. [Creativity in preschool]. (pp. 1-15), Eskisehir: Anadolu Universitesi Acikogretim Fakultesi Yayinlari.

Temizkan, M. (2003). Yazili anlatim etkinligi cercevesinde Turkce ogretmenlerinin calismalarina iliskin bir degerlendirme. [An evaluation of Turkish teachers applications on the written comprehension activities in elementary schools]. (Unpublished master's thesis), Hatay: Mustafa Kemal University Institute of Social Sciences.

Tufekcioglu, B. (2010). Yazma becerisinin bazi degiskenler acisindan incelenmesi. [Examination of writing skill in terms of some variables]. Dil Dergisi, (149), 30-45.

Weigle, S.C. (2007). Assessing writing. UK, Cambridge: Cambridge University Press. 